\title{
Perbedaan Kadar Kalsium Dalam Saliva Sebelum Dan Sesudah Mengkonsumsi Minuman Ringan Ringan yang mengandung asam Bikarbonat
}

\section{Muhammad Ilyas, ${ }^{*}$ M.Yusri ${ }^{\star \star}$}

* Bagian Ilmu Kesehatan Gigi Masyarakat

** Mahasiswa tingkat kepaniteraan

Fakultas Kedokteran Gigi Universitas Hasanuddin

Makassar, Indonesia

\begin{abstract}
The increasing consumption of soft drink has developed anxiety in health extraordinary in population. Many studies have showed the negative impacts of soft drink for human health. This study aimed to know the difference of calcium and in saliva before and after consumed soft drink contained bicarbonate acid. The quasi experiment prepation time series design was conducted at BTPT laboratory in Maros of South Sulawesi by using 5 marmots in examination with 600 grams or over body weigth average, and 70 days of age or over. Data were analyzed using SPSS versi 11 for windows withAnova, continued with LSD test. The are different of calcium in saliva level before and after consumtion of soft drink which contain acid bicarbonate in minute 5, 10, 15, and 20 treatment with $p=0.000$. Key words: Calcium level, saliva, bicarbonate acid
\end{abstract}

\section{ABSTRAK \\ Meningkatnya konsumsi minuman ringan telah menimbulkan kecemasan yang luar biasa di kalangan kesehatan. Banyak penelitian yang telah membuktikan dampak negatif minuman ringan bagi kesehatan manusia. Penelitian bertujuan untuk mengetahui perbedaan kalsium dalam saliva sebelum dan setelah mengkonsumsi minuman ringan yang mengandung asam bikarbonat dan untuk mengetahui waktu kelarutan kalsium setelah mengkosumsi minuman ringanyangmengandungasam bikarbonat. Penelitian ini bersifat eksperimental semu dengan rancangan time series design, dilakukan di t Laboratorium BPTP Maros Sulawesi Selatan dengan jumlah subjek perlakuan 5 ekor marmot dengan berat badan $>600$ gram dan}


umur > 70 hari serta mempunyai gigi yang sehat semua. Data dianalisis dengan menggunakan program SPSS versi 11 for windows dengan uji Anova yang dilanjutkan dengan uji LSD. Ada perbedaan secara signifikan kadar kalsium dalam saliva sebelum dan sesudah mengkonsumsi minuman ringan yang mengandung asam bikarbonat padamenitke-5, 10,15, dan ke-20 dengan $p=0,000$.

Kata kunci: Kadar kalsium, saliva, asam bikarbonat.

Correspondence: Muhammad Ilyas, Bagian IImu Kesehatan Gigi Masyarakat, Fakultas Kedokteran Gigi Universitas Hasanuddin, Jl. Perintis Kemerdekaan KM. 10, Tamalanrea Makassar, Indonesia.

\section{PENDAHULUAN}

Email dan dentin gigi
merupakan jaringan keras dan mempunyai fungsi sebagai pelindung pulpa, namun demikian keduanya mempunyai persamaan, antara lain dibentuk oleh berbagai mineral, yang salah satu diantaranya adalah kalsium Salivayang merupakan cairan dalam mulut, salah satu fungsinya adalah sebagai buffer yang dapat menahan turunnya $\mathrm{pH}$ atau meningkatnya keasaman mulut. Kondisi ini tergantung dari keadaan saliva sendiri apakah viskositas atau volumenya cukup untuk menjaga kestabilan sehingga email, sementum atau dentin gigi tidak mengalami kelarutan. ${ }^{1}$

Adapun pengaruh buffer tersebut belum diketahui secara pasti kapan atau berapa lama setelah terpapar zat asam dapat menetralkan kembali $\mathrm{pH}$ dalam mulut. Apabila $\mathrm{pH}$ dalam mulut di atas 5,5 melalui aksi buffer dari saliva maka terjadi proses supersaturasi ion $\mathrm{Ca}^{+2}$ dan P04. Pada situasi ini jaringan keras gigi dapat menarik ion atau elemen-elemen yang dikenal sebagai proses remineralisasi. 1 Sebaliknya jika $\mathrm{pH}$ mulut di bawah titik kritis $(\mathrm{pH}<5.5)$, maka akan terjadi subsaturasi ion $\mathrm{Ca}^{+2}$ dan $\mathrm{PCM}$ " yang menyebabkan kelarutan minera email gigi ke lingkungan dalam mulut yang disebutdemineralisasi. ${ }^{4}$

Demineralisasi email terjadi melalui proses difusi, yaitu terjadinya perpindahan molekul/ion yang larut dalam air atau dari dalam email ke saliva karena adanya perbedaan konsentrasi dari asam di permukaan dengan di dalam email gigi. Asamasam minuman yang mempunyai konsentrasi tinggi dan $\mathrm{pH}$ awal 
minuman yang rendah akan berdifusi ke dalam email melalui kristal-kristal dan kisi-kisi prisma tubuli email yang mengandung air dan matriks organic. ${ }^{45}$

Para peneliti mengemukakan bahwa semakin sering gigi berkontak dengan minuman ringan yang mengandung asam maka makin besar pula terjadinya kelarutan mineral email gigi dalam saliva.

Konsumsi minuman ringan seharihari sangat banyak di kalangan anakanak dan remaja yang berkaitan dengan jumlah modifikasi yang tejadi pada permukaan email maupun dentin yang terpapar. ${ }^{1,7}$

Saliva merupakan salah satu faktor penting untuk melindungi permukaan gigi terhadap pengaruh asam. Penelitian menunjukkan bahwa erosi serigkali ditemukan pada daerah gigi yag tidak memiliki cukup pelikel. Meningkatnya aliran saliva berperan penting pada akumulasi pelikel bersamaan dengan peningkatan aksi buffer dari saliva. ${ }^{8}$

Saliva dalam rongga mulut yang dihasilkan oleh tiga pasang kelenjar saliva besar (parotis, submandibularis dan lingualis), kelenjar saliva minor dan cairan gingiva. Zat ini terdiri 99,5 \% berupa cairan dan sisanya merupakan komponen-komponen yang larut dibedakan atas komponen anorganik elektrolit dalam bentuk ion, seperti $\mathrm{Na}^{+}, \mathrm{K}^{+}, \mathrm{Ca}^{2}, \mathrm{Mg}^{2+}, \mathrm{Cl}$, dan fosfat, dan komponen organik terutama protein, musin, lipida, asam lemak dan ureum.

Susunan kuantitatif dan kualitattif elektrolit di dalam saliva menentukan $\mathrm{pH}$ dan kapasitas buffer. Derajat keasaman saliva tergantung dari perbandingan antara asam dengan kapasitas buffer terutama disebabkan oleh susunan bikarbonat yang naik dengan kecepatan sekresi. Ini berarti $\mathrm{pH}$ dan kapasitas buffer saliva juga naik dengan naiknya kecepatan sekresi. $^{1}$

Kapasitas cairan buffer dapat didefinisikan sebagai suatu kemampuan untuk menahan perubahan $\mathrm{pH}$. Hal ini diperlukan karena bila mengkonsumsi makanan atau minuman ringan yang asam dapat menurunkan $\mathrm{pH}$ saliva.

Email merupakan lapisan terluar dari gigi yang terbentuk dari tongkattongkat kristal yang tersusun dalam ikatan kompleks kalsiumhidroksiapatit. Kalsium ini sangat menentukan kekerasan permukaan email gigi, tetapi juga dipengaruhi oleh keadaan saliva terutama yang mempunyai $\mathrm{pH}$ rendah sehingga fungsi sebagai buffer terganggu, 
sehingga pada akhirnya menimbulkan kelarutan mineral email gigi.

Asam itu berdifusi ke dalam email, terionisasi menjadi FT dan L". Ion $\mathrm{H}^{+}$ merusak kalsium hidroksiapatit, menguraikannya menjadi ion-ion $\mathrm{Ca}^{+2}$, $\mathrm{OH}^{\prime \prime}, \mathrm{P} 4^{1}$ dan ion $\mathrm{F}^{11}$. Ion-ion yang terbentuk masuk ke dalam larutan email gigi dan membentuk senyawa kompleks Ca (H2P04)2, CaHP04 dan CaL2. Setelah konsentrasi senyawa kompleks itu cukup tinggi, secara difusi molekul-molekul tersebut keluar ke saliva dan sebagian daripadanya akan terionisasi kembali. Proses demineralisasi baru berhenti bila konsentrasi HL dalam mulut rendah dan konsentrasi kalsium atau posfor dalam saliva tinggi serta terjadi proses remineralisasi. ${ }^{4}$

Demineralisasi email terjadi melalui proses difusi, yaitu berperpindahnya molekul/ion yang larut dalam air atau dari dalam email ke saliva karena adanya perbedaan konsentrasi dari asam, minuman di permukaan dengan di dalam email gigi. Asam-asam minuman yang mempunyai konsentrasi tinggi dan $\mathrm{pH}$ awal minuman yang rendah akan berdifusi ke dalam email melalui kristal-kristal dan kisi-kisi prisma tubuh email yang mengandung air dan matriksorganik. ${ }^{4 S}$
Adapun minuman ringan yang beredar di tengah masyarakat sekarang umumnya bersifat asam, salah satu diantaranya yaitu yang mengandung asam bikarbonat. Proses kelarutan mineral email gigi karena konsumsi minuman ringan yang mengandung asam tentunya membutuhkan waktu yang sampai saat ini informasi mengenai hal tersebut belum diketahui secara pasti. Berdasarkan dari latar belakang di atas, maka dapat perlu diketahui sebagai berikut, yaitu bagaimana perbedaan kadar mineral kasium dalam saliva sebelum dan setelah mengkonsumsi minuman ringan yang mengandung asam bikarbonat, dan berapa lama setelah konsumsi minuman ringan yang mengandung asam sehingga terjadi kelarutan mineral kalsium dari email gigi.

Tujuan penelitian penelitian ini adalah untuk mengetahui perbedaan kadar mineral kalsium dalam saliva sebelum dan setelah mengkonsumsi minuman ringan yang mengandung asam bikarbonat, dan untuk mengetahui waktu setelah konsumsi minuman ringan yang mengandung asam dapat menyebabkan kelarutan kalsium dari email gigi. Manfaatnya adalah masyarakat dapat mengetahui pengaruh minuman ringan yang 
mengandung asam terhadap kesehatan gigi, dan mendukung program pencapaian derajat kesehatan gigi dan mulut pada Indonesia Sehat tahun 2010.

\section{BAHAN DAN METODE}

Jenis penelitian ini adalah eksperimen semu dengan rancangan time series design menggunakan spektrometer atom di Laboratorium BPTP kabupaten Maros Sulawesi Selatan. Subjek perlakuan yaitu marmot (cavea aperea) sebanyak lima ekor dengan kriteria berat badan $>600$ gram, umur > 70 hari, mempunyai gigi yang sehat. Penelitian dilaksanakan pada bulan Oktober 2006.

Analisis data menggunakan program SPSS versi 11 for Windows.
Uji Anova digunakan untuk mengetahui nilai rerata perbedaan kelarutan kadar kalsium sebelum dan sesudah mengkonsumsi minuman ringan yang mengandung asam sitrat dilanjutkan dengan dengan uji LSD untuk mengetahui ada tidaknya perbedaan yang bermakna antara sebelum dan sesudah mengkonsumsi minuman ringan.

\section{HASIL PENELITIAN}

Pada tabel 1, dengan uji Anova diketahui ada perbedaan bermakna rerata kadar kalsium sebelum dan setelah mengkonsumsi minuman ringan yang mengandung asam bikarbonat.

Tabel 1. Rerata perbedaan kadar kalsium sebelum dan sesudah konsumsi minuman ringan yang mengandung asam bikarbonat

\begin{tabular}{lccccc}
\hline & N & Waktu (menit) & Mean (ppm) & SD & P \\
\hline & 5 & Sebelum & 3,93 & 3,93 & \\
Asam Bikarbonat & $\mathbf{5}$ & 5 & 153.66 & 14,46 & \\
& 5 & 10 & 242,90 & 14,77 & \\
& 5 & 15 & 339,49 & 24,47 & $0.000^{*}$ \\
& 5 & 20 & 366,12 & 37,29 & \\
& 5 & 25 & 335,67 & 30,77 & \\
& 5 & 30 & 233,92 & 17,65 & \\
& 5 & 35 & 155,31 & 39.99 & \\
\hline
\end{tabular}


Tabel 2. Perbedaan kadar kalsium sebelum dan sesudah mengkonsumsi minuman ringan yang mengandung bikarbonat berdasarkan waktu.

\begin{tabular}{lllllllll}
\hline Perlakuan & Sebelum & 5 menit & 10 menit & 15 menit & 20 menit & 25 menit & 30 menit & 35 menit \\
\hline Sebelum & - & $0,000^{*}$ & $0,000^{*}$ & $0,000^{*}$ & $0,000^{*}$ & $0,000^{*}$ & $0,000^{*}$ & $0,000^{*}$ \\
5 menit & - & $0,000^{*}$ & & $0,000^{*}$ & $0,000^{*}$ & $0,000^{*}$ & $0,000^{*}$ & 0,920 \\
10 menit & - & - & & $0,000^{*}$ & $0,000^{*}$ & $0,000^{*}$ & 0,585 & $0,000^{*}$ \\
15 menit & - & - & - & 0,111 & 0,816 & $0,000^{*}$ & $0,000^{*}$ \\
20 menit & - & - & - & - & 0,076 & $0,000^{*}$ & $0,000^{*}$ \\
25 menit & - & - & - & - & - & $0,000^{*}$ & $0,000^{*}$ \\
30 menit & - & - & - & - & - & - & $0,000^{*}$ \\
35 menit & - & - & - & - & - & - & \\
\hline
\end{tabular}

Uji LSD: *Signifikan $p<-0,05$

Dari uji beda lanjut (LSD) di atas diperoleh hasil yang signifikan antara kadar kalsium dalam saliva sebelum dan setelah mengkonsumsi minuman ringan yang mengandung asam bikarbonat berdasarkan waktu pemberian. Akan tetapi tidak ada perbedaan yang bermakna antara waktu pemberian pada 5 menit dengan 35 menit, 10 menit dengan 30 menit, 15 menit dengan 20 dan 25 menit, 20 menit dengan 25 menit.

\section{DISKUSI}

Pada tabel I terlihat ada peningkatan kadar kalsium dalam saliva sesudah mengkonsumsi minuman ringan yang mengandung asam bikarbonat. Hal ini disebabkan karena minuman ringan berkarbonat memliki $\mathrm{pH}$ yang sangat rendah atau di bawah $\mathrm{pH}$ kritis sehingga sesudah dikonsumsi menyebabkan terjadinya keasaman dalam mulut. ${ }^{8}$

Hal ini sesuai dengan penelitian sebelumnya, yaitu minuman ringan berkarbonat bersifat asam sangat potensial menyebabkan demineralisai email gigi. Ini disebabkan asam pada minuman ringan bertindak sebagai selator yang mengikat mineral apatit seperti kalsium. Jumlah garam kalsium yang larut dalam saliva akan sebanding dengan kalsium yang keluar dari saliva dan disimpan dalam email gigi. Jika $\mathrm{pH}$ asam kesimbangan tadi akan berpengaruh dan iebih banyak garam yang keluar daripada yang masuk. ${ }^{9,10}$

Idealnya $\mathrm{pH}$ saliva berkisar dari 5,5 hingga 5,6. daerajat keasaman 5,5 secara umum dianggap sebagai nilai batas kerusakan gigi walaupun rongga mulut dapat menetralkan kembali $\mathrm{pH}$ 
yang berada di bawah nilai am bang batas tersebut, tetapi jangka waktu keterpaparan antara $\mathrm{pH}$ netral menjadi $\mathrm{pH}$ di bawah ambang batas dapat menghasilkan peningkatan laju demineralisasi email.

Pada tabel 2 dari hasil uji beda lanjut, diperoleh hasil yang tidak signifikan tentang kadar kalsium pada saliva pada 5 menitdengan 30 menit, IOmenit dengan 30 menit, 15 menit dengan 20 menit dan 25 menit serta 20 menit dengan 25 menit. Hal ini disebabkan oleh $\mathrm{pH}$ mulut menjadi asam 5-30 menit setelah mengkonsumsi makanan atau minuman yang bersifat asam dan akan normal kembali karena adanya fungsi buffer saliva. $^{7}$

\section{SIMPULAN}

Dari hasil penelitian ini dapat disimpulkan bahwa ada perbedaan kadar saliva sebelum dan sesudah mengkonsumsi minuman ringan yang mengandung asam bikarbonat, dan terjadi peningkatan kadar kalsium dalam saliva mulai dari 5 menit sampai 20 menit sesudah mengkonsumsi minuman ringan yang mengandung asam bikarbonat, kemudian kadar kalsium menurun kembali atau menjadi normal mulai menit ke- 25.

\section{SARAN}

Mengingat pentingnya hasil penelitian ini, maka dapat disarankan kiranya perusahaan minuman ringan mau diajak kerjasama dalam memproduksi khususnya yang mengandung asam bikarbonat.

\section{UC APAN TERIMA KASIH}

Penelitian ini didanai oleh Hibah Penelitian PHK A2 FKG Unhas 2005

\section{DAFTARPUSTAKA}

1. Anonim. Diagnosis and management of dental erosion. Available at: http//www. Theicdp.com/issue001/gandra/cau ses.htm. Diakses tanggal 12 Juli 2006.

2. Nylund J. The harmful effects of soft drinks.

3. North Lake Collage; 2002. Barron RP, Marcon.MA, Sandor KB. Dental erosion in gastroesophageal reflux disease. $J$ Can Dent Assoc 2003; 64 (2): 8490.

4. Seow WK, Thong KM. Erosive' effects of common beverages on extracted premolar teeth. AustrDentJ2005,50(3): 173-8.

5. Mok TB, Mclntyre, Hunt D: Dental erosion in vitro model of wine 
assessor's erosion. Austr Dent $\mathrm{J}$ 2001; 46 (14): 263-4.

6. Duarte MB, Andries VB. Salivary secretion and chewing: stimulatory effects from artificial and natural foods. JAppl Oral Sci 2004; 12(2): 160.

7. Attin T, Weiss K, Becker K. Impact of modified acidic soft drinks on enamel erosion oral diseases. 2005; 11:7,12.

8. Agnes SJ, Widijanto: Peranan berbagai sifat kandungan minuman ringan terhadap potensinya dalam mendemineralisasi gigi. Ceramah
Singkat Rimbawanla 1996; hal. 613-9.

9. Amerongen AVN, Bolscher JGM, Veerman ECL. Salivary protein protective and diagnositic value in cariology. Caries Res 2004; 38,274 .

10. Willwey VCH. Why was the exisstance of carbionic acid unfoirly doubted for so long. Available form: URL:http://www. WILEY-VCH Angewandte Chemie Internaional htm. Ang Chem Int Ed 2000; 39 (5): 891 -4. Tanggal diakses: April 52006 